\title{
Moisture content of cereals at harvesting time by comparing microclimate values and standard weather data
}

\author{
A,J. ATZEMA \\ Department of Meteorology, Wageningen Agricultural University, Duivendaal 2, NL 6701 \\ AP Wageningen, Netherlands \\ Received 3 December 1992; accepted 17 March 1993
}

\begin{abstract}
The relationship between standard weather data and the microclimate of wheat and barley during harvesting time has been determined. The moisture content of wheat and barley together with the weather elements have been measured at 3 different experimental sites in the Netherlands in the harvesting seasons of 1990 and 1991. The difference in the dew point temperature in the screen and in the field is small. However, the differences between air temperature in the screen and those at different heights in wheat as well as in barley are considerable. In daytime the surface temperature of barley is higher than that of wheat under the same weather conditions as a result of a higher absorbtion coefficient. Both for wheat and barley, the maximum difference between the calculated moisture content is $0.5 \%$, using the air temperature at $1.5 \mathrm{~m}$ height from the nearest standard weather station and the surface temperature of the ears. Barley has a greater daily cycle in the moisture content of the grains than wheat as a result of a high equilibrium moisture content during the night and a low one in daytime.
\end{abstract}

Keywords: moisture content, temperature, wheat, barley, harvesting time

\section{Introduction}

The weather has a great influence on the moisture content of the grains of cereals during harvesting time. The prediction of the moisture content of the grains of cereals through the input of standard weather elements into a model has been described by Atzema (1993). In literature little is known about the relationship between standard weather data and the microclimate of cereals. Van Eimern (1964) described the rclationship between temperatures at different heights within immature cereals (barley and wheat) and screen temperature. In mature wheat differences between surface temperature of the ear at $1.2 \mathrm{~m}$ and air temperature at $1.2 \mathrm{~m}$ are described. Beinhauer (1975) shows the relationship between the mean values of air temperature within immature wheat crop and screen temperature. Both Van Eimern and Beinhauer, showed in daytime the measured temperatures in the stands of wheat and barley are higher than the screen temperatures. 
The difference in temperatures of the ears in wheat and in barley can be great. The reflection coefficient for wheat and barley is 26 and 23, respectively (Monteith, 1990). The transmission of radiation in barley is $50 \%$ (Monteith, 1969). The ears of barley bent downward which provides the surface of the crop is more closed. Also the leaves of barley are more horizontal than that of wheat (Ross, 1975). Therefore the transmission of radiation in wheat is more than $50 \%$. So the absorbtion coefficient is less than 24 for wheat and 27 for barley. This is the reason in daytime the temperature of the ears of barley is higher than that of wheat under the same weather conditions,

The aim of the present research program is to forecast the moisture content of the grains of cereals at harvesting time by a weather-driven model. This paper only describes the response of the moisture content of wheat and barley to the weather elements. The moisture content is influenced by the temperature of the grains, which has to be estimated from the air temperature at $1.5 \mathrm{~m}$ height as measured at standard weather stations. Only then the moisture content of cereals can be calculated by a model using the input of realtime weather data. The model uses six meteorological clements, namely air temperature, dew point temperature, both at screen height, wind speed at $10 \mathrm{~m}$ height, amount of rain, global radiation and cloud cover. All weather elements are taken hourly, except the quantity of rain which is taken every 6 hours (Atzema, 1993).

In practice farmers are only interested in the moisture content of cereals at threshing, During harvesting, the straw moisture content influences the moisture content of the grains. Usually the grains are ripe earlier than the straw and the lower part of the straw is wetter than the upper part of the straw. Also (green) weeds can increase the moisture content of the grains at harvesting, because moisture is pressed out of the weeds and moisten the grains (Van Kampen, 1969). Therefore the differences of the moisture content of the grains are also compared before and after threshing.

\section{Material and methods}

During the harvesting season of 1990 and 1991 the moisture content of mature barley and wheat (from stadia DC 91) together with weather elements have been measured at 3 different experimental sites in the Netherlands: in the South-East (Kessel), in the South-West (Haamstede) and in the North-East (Weiwerd). The meteorological data of the experimental sites are compared with those of the nearest standard weather stations (Volkel, Vlissingen and Eelde, respectively). Table 1 shows the locations of the experimental sites and the standard weather stations.

Table 2 shows the periods of time the experiments were carried out. In the Netherlands the harvesting time of cereals always start in the South-East, continuing in the South-West (some days till one week later) and finishes in the North-East (on average 3 weeks later than in the South-East). During the harvesting time of wheat in 1990 , it was very hot. This is the reason why the differences in the harvesting time between the different regions were very small. In 1991 on the other hand the harvesting time started late as a consequence of cold weather during the growing season.

The size of the experimental sites were at least 1 ha and those in Weiwerd were 
Table 1. The locations of the experimental sites and the standard weather stations.

\begin{tabular}{|c|c|c|}
\hline Type of site & Site & Geographic position \\
\hline Experimental site & $\begin{array}{l}\text { Kessel } \\
\text { Haamstede } \\
\text { Weiwerd }\end{array}$ & $\begin{array}{ll}51^{\circ} 18^{\prime} \mathrm{N} & 6^{\circ} 04^{\prime} \mathrm{E} \\
51^{\circ} 42^{\prime} \mathrm{N} & 3^{\circ} 45^{\prime} \mathrm{E} \\
53^{\circ} 19^{\prime} \mathrm{N} & 6^{\circ} 56^{\prime} \mathrm{E}\end{array}$ \\
\hline $\begin{array}{l}\text { Standard } \\
\text { weather } \\
\text { station }\end{array}$ & $\begin{array}{l}\text { Volkel } \\
\text { Vlissingen } \\
\text { Eelde }\end{array}$ & $\begin{array}{ll}51^{\circ} 39^{\prime} \mathrm{N} & 5^{\circ} 42^{\prime} \mathrm{E} \\
51^{\circ} 27 ' \mathrm{~N} & 3^{\circ} 36^{\prime} \mathrm{E} \\
53^{\circ} 08^{\prime} \mathrm{N} & 6^{\circ} 35^{\prime} \mathrm{E}\end{array}$ \\
\hline
\end{tabular}

Table 2, The periods of time the experiments were carried out.

\begin{tabular}{|c|c|c|c|}
\hline Year & Site & Crop & Time \\
\hline 1990 & $\begin{array}{l}\text { Kessel } \\
\text { Haamstede } \\
\text { Kessel } \\
\text { Haamstede } \\
\text { Weiwerd }\end{array}$ & $\begin{array}{l}\text { barley } \\
\text { barley } \\
\text { wheat } \\
\text { wheat } \\
\text { wheat }\end{array}$ & $\begin{array}{l}\text { 11-13 July } \\
26-30 \text { July } \\
24 \text { July-2 August } \\
\text { 1-4 August } \\
\text { 4-12 August }\end{array}$ \\
\hline 1991 & $\begin{array}{l}\text { Weiwerd } \\
\text { Weiwerd }\end{array}$ & $\begin{array}{l}\text { barley } \\
\text { barley }\end{array}$ & $\begin{array}{l}28-30 \text { July } \\
21-23 \text { August }\end{array}$ \\
\hline
\end{tabular}

situated in an area with a lot of cereals. The measurements were performed each hour from dawn till dusk. A sample of ears was taken in the field at random. After threshing by hand with the help of sandpaper, the moisture content of the grains was determined (six-fold samples) by a cereal moisture content meter (type Protimeter Digital Grainmaster). In this machine the grains were ground before measuring. The air temperature and dew point temperature were measured with an Assmann psychrometer. The surface temperature of the ears has been determined by a infrared radiation thermometer (type CHINO Portable Radiation Thermometer Comet 8000). The global radiation has been measured by a pyranometer (type Kipp CM5).

To compare the moisture content of the grains before and after threshing, a sample of cars in the field just before combining and a sample of grains just after combining were taken.

At drying the moisture content of the grains of cereals can be calculated using the formula of Penman-Monteith (Monteith, 1965):

$$
L_{v} E=\frac{s R_{n}+\frac{\rho_{a} c_{p}\left(e_{s}-e_{a}\right)}{r_{a}}}{s+\gamma\left(1+\frac{r_{c}}{r_{a}}\right)}
$$

The net radiation can be calculated (Holtslag \& Van Ulden, 1983) by:

$$
R_{n}=\frac{a R_{g}+c_{1} T^{6}-\sigma T^{4}+c_{2} N}{1+c_{3}}
$$


The height of the crop is set at $0.8 \mathrm{~m}$ and the wind speed ( $10 \mathrm{~m}$ height) is taken 2 $\mathrm{m} \mathrm{s}^{-1}$. Therefore $\mathrm{r}_{\mathrm{a}}$ is $62 \mathrm{~s} \mathrm{~m}^{-1}$ and at a moisture content of $16 \% \mathrm{r}_{\mathrm{c}}$ is $21875 \mathrm{~s} \mathrm{~m}^{-1}$ (Atzema, 1993).

The equilibrium moisture content $\mathrm{M}_{\mathrm{e}}$ is calculated by the Henderson equation (Henderson, 1952). The modified version of the Henderson equation is (Anon., 1982):

$M_{c}=\left[\frac{\ln \left(1-\frac{e_{a}}{e_{s}}\right)}{-c_{4}\left(T+c_{5}\right)}\right]^{\frac{1}{c_{4}}}$

\section{Results and discussion}

Both in wheat as well as in barley there is no significant difference in the dew point temperature ( $1.5 \mathrm{~m}$ height) between the experimental plot and the nearest weather station. The difference in the dew point temperature in the screen and in the field is $0.7 \pm 1.7^{\circ} \mathrm{C}(\mathrm{n}=260)$ and $0.1 \pm 1.4^{\circ} \mathrm{C}(\mathrm{n}=114)$ for wheat and barley, respectively. However, the differences in the air temperatures are considerable.

Figure 1 shows the mean hourly temperatures in wheat of 3 successive days within the same air mass (Haamstede; 1 until 3 August 1990): the air temperature at $1.5 \mathrm{~m}$ height at the nearest standard weather station, the surface temperature of the ears, the air temperature at the height of the ears $(1.0 \mathrm{~m}$ height) and above the canopy (1.5 $\mathrm{m}$ height). The surface temperature has the largest daily cycle. The maximum air temperature is reached late in the afternoon, since this temperature is dependent on the heat flux from the underlying surface. At daytime, the air temperature above the canopy ( $1.5 \mathrm{~m}$ height) is greater than that in the screen above short grass. The air is heated from the surface of the crop and the distance above the wheat is small compared to that above grass. Also the air temperature in the neighbourhood of the ears ( $1.0 \mathrm{~m}$ height) is higher than that above the canopy ( $1.5 \mathrm{~m}$ height).

Figure 2 shows the mean hourly temperatures in barley of 4 successive days within the same air mass (Haamstede; 26 until 29 July 1990): the air temperature at $1.5 \mathrm{~m}$ height at the nearest standard weather station, the surface temperature of the ears, the air temperature at the height of the ears $(0.7 \mathrm{~m}$ height) and above the canopy ( 1.5 $\mathrm{m}$ height). In barley the difference between the surface temperature and the other temperatures is greater than that in wheat. Barley absorbs more heat than wheat under the same weather conditions.

In Table 3 and 4 the theoretical maximum differences in moisture content has been calculated for wheat and barley, respectively, when using the air temperature from the nearest standard weather station and the surface temperature of the grains, at daytime. The input of the weather elements are the mean values of the experiments in 1990 and 1991 (for wheat 18 days and for barley 10 days) under dry weather conditions only. The mean dew point temperature is $14^{\circ} \mathrm{C}$ and the sky is cloudless. The yield of the wheat and barley is estimated at 7000 and $5500 \mathrm{~kg} \mathrm{ha}^{-1}$, respectively. So at a moisture content of $16 \%$ only 1120 and $880 \mathrm{~kg} \mathrm{ha}^{-1}$ water is present for wheat 


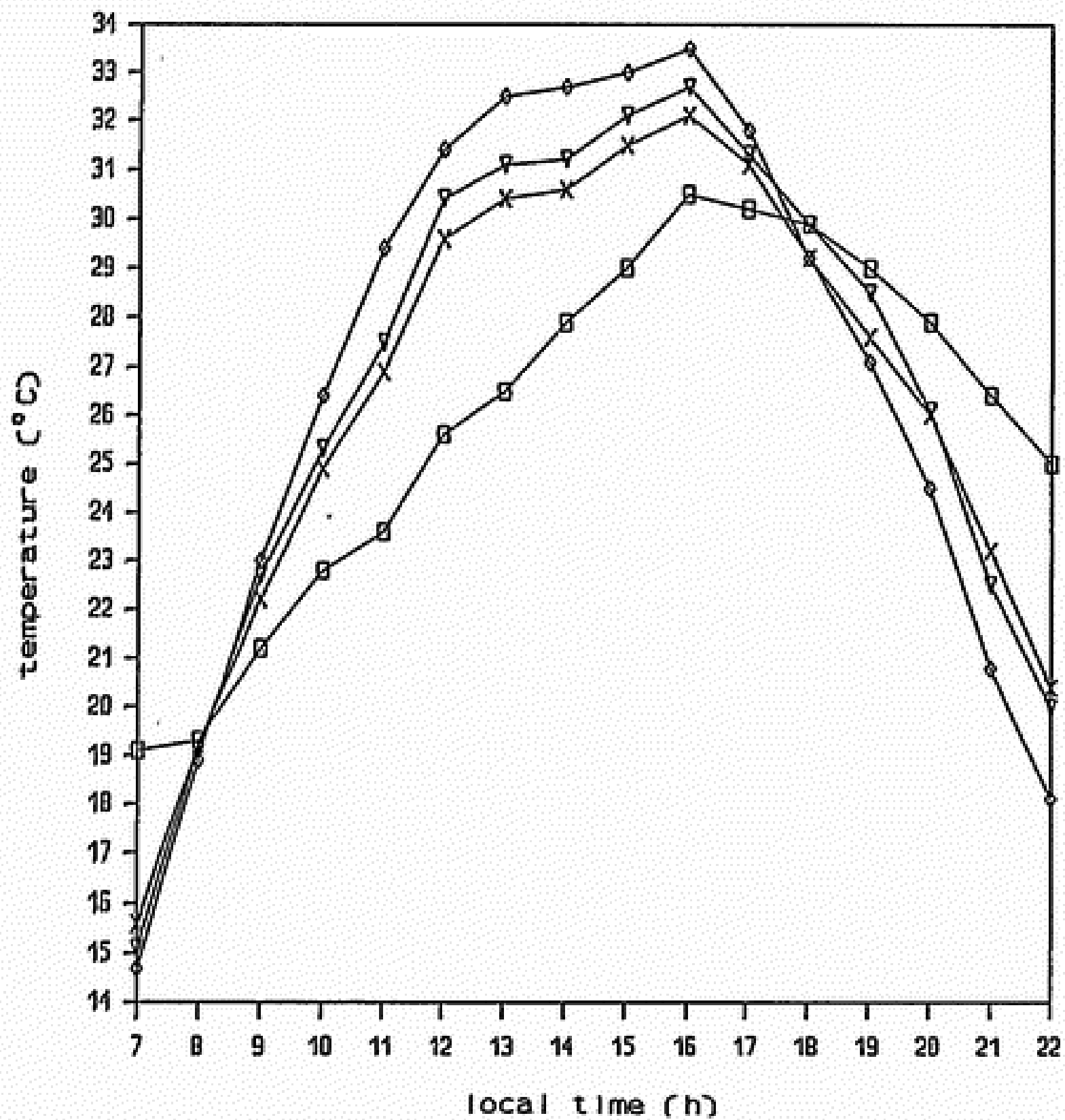

Fig. I, Mean hourly temperatures in wheat at Haamstede and the corresponding screen temperature at Vlissingen of 3 successive days (1-3 August 1990). $\diamond$ surface temperature of the ears; $\nabla$ air temperatu$r e$ in wheat at $1.0 \mathrm{~m}$ height; $X$ air temperature in wheat at $1.5 \mathrm{~m}$ height; $\square$ screen temperature at Vlissingen,

and barley, respectively. Despite in these experiments the maximum difference in temperature is $7{ }^{\circ} \mathrm{C}$, the maximum difference in grain moisture content is only $0.5 \%$, both for wheat and barley. Because under the same weather conditions barley absorbs more heat than wheat, the difference in moisture content of barley appears carly in the day.

To have a constant crop resistance, every hour the moisture content was reset at $16 \%$. So the differences in moisture content can not be added. In reality the differences between the calculated moisture content and the moisture content in the field is smaller. Firstly, the temperature of the grains is lower than the surface temperature of the grains. Secondly, a higher temperature decreases the moisture content of the cereals with the consequence the crop resistance increases considerable. 


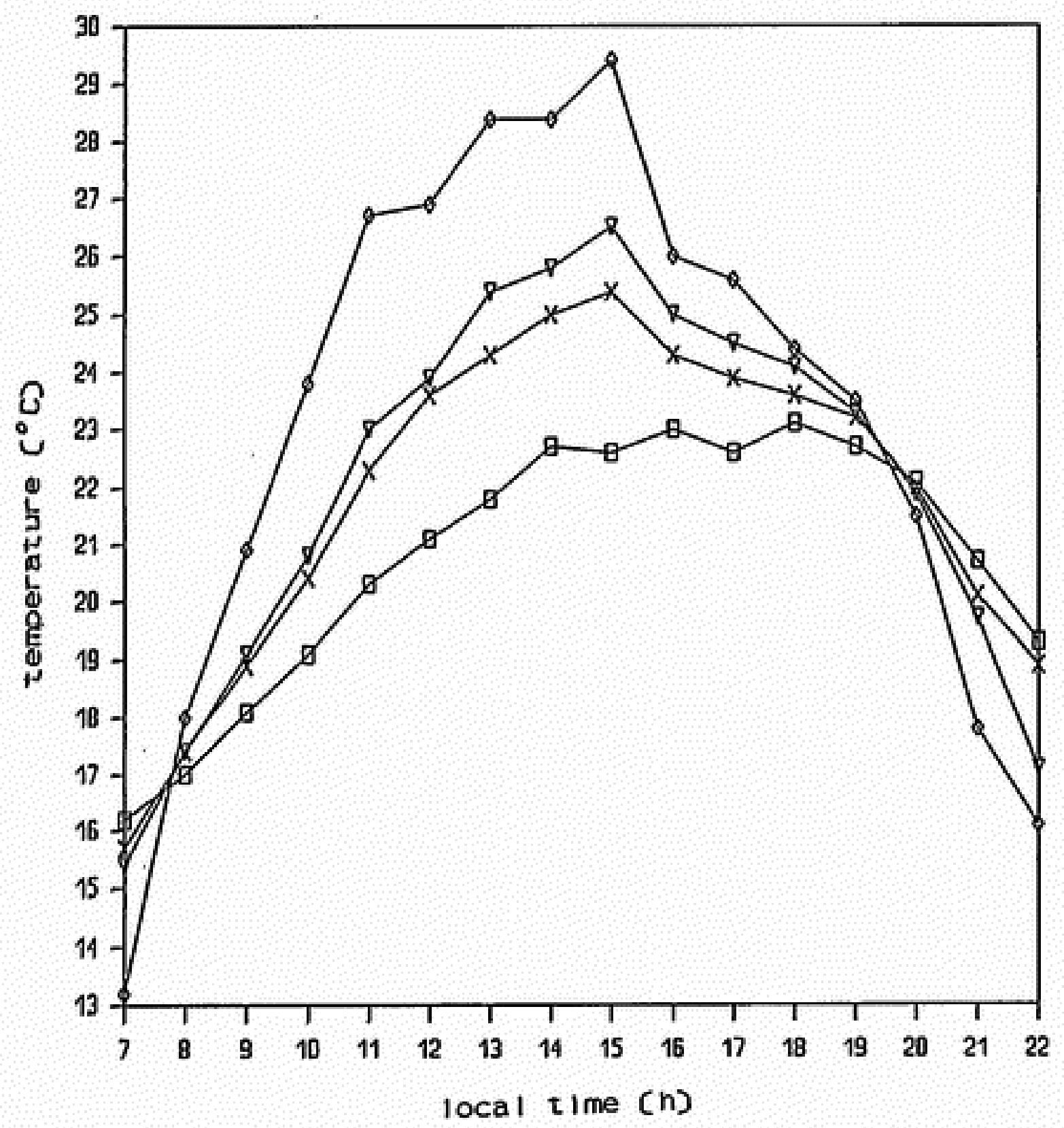

Fig. 2. Mean hourly temperatures in barley at Haamstede and the corresponding screen temperature at Vlissingen of 4 successive days (26-29 July 1990). $\Delta$ surface temperature of the ears; $\nabla$ air temperature in barley at $0.7 \mathrm{~m}$ height; $\times$ air temperature in barley at $1.5 \mathrm{~m}$ height; $\square$ screen temperature at Vlissingen.

Figure 3 shows the course of the average moisture content of wheat (18 days) and barley (10 days) during the day. Compared to wheat, in the morning the moisture content of barley decreases rapidly and in the evening the moisture content of barley increases rapidly. These results agree with those of Van Kampen (1969).

The minimum quantity of absorbed water of the grains depend on the temperature and the dew point temperature of the surrounding air. This moisture content is the equilibrium moisture content. Water left in the grains is bound too strongly. Figure 4 shows the calculated equilibrium moisture content of wheat and barley with varying air temperature. The dew point temperature is set at $14^{\circ} \mathrm{C}$. From Tables 3 and 4 it can be seen that during the wheat experiments the average air temperature was higher than that during the barley experiments. With an equal dew point temperature 


\section{MOISTURE CONTENT OF CEREALS AT HARVESTING}

Table 3. Percentage difference in moisture content $(\Delta)$ in wheat calculated using the air temperature from the nearest weather station $\left(T_{2,5 t}\right)$ or the surface temperature of the ears $\left(T_{3}\right)$. Every hour (local time) the temperatures and the global radiation $\left(R_{\mathrm{g}}\right)$ are the mean values during 18 experimental days under dry weather conditions.

\begin{tabular}{lllll}
\hline $\begin{array}{l}\text { Time } \\
(\mathrm{h})\end{array}$ & $\begin{array}{l}\mathrm{T}_{\mathrm{g} \text { st }} \\
\left({ }^{\circ} \mathrm{C}\right)\end{array}$ & $\begin{array}{l}\mathrm{T}_{\mathrm{s}} \\
\left({ }^{\circ} \mathrm{C}\right)\end{array}$ & $\begin{array}{l}\mathrm{R}_{\mathrm{g}} \\
\left(\mathrm{Jcm}^{-2} \mathrm{~h}^{-1}\right)\end{array}$ & $\begin{array}{l}\Delta \\
(\%)\end{array}$ \\
8 & 16.2 & 18.5 & 57 & 0.05 \\
9 & 18.9 & 22.4 & 81 & 0.11 \\
10 & 21.2 & 26.2 & 156 & 0.23 \\
11 & 22.5 & 28.5 & 179 & 0.31 \\
12 & 23.4 & 30.0 & 202 & 0.38 \\
13 & 24.2 & 30.5 & 252 & 0.42 \\
14 & 24.6 & 31.4 & 258 & 0.49 \\
15 & 25.5 & 30.5 & 235 & 0.34 \\
16 & 26.0 & 29.8 & 221 & 0.24 \\
17 & 25.5 & 28.2 & 181 & 0.16 \\
18 & 24.3 & 26.8 & 141 & 0.11 \\
19 & 23,6 & 25.5 & 96 & 0.07 \\
20 & 22.4 & 23.0 & 55 & 0.02 \\
\hline
\end{tabular}

Table 4, Pereentage difference in moisture content $(\Delta)$ in barley calculated using the air temperature from the nearest weather station $\left(\mathrm{T}_{2, s t}\right)$ or the surface temperature of the ears $\left(\mathrm{T}_{2}\right)$. Every hour (local time) the temperatures and the global radiation $\left(\mathrm{R}_{\mathrm{g}}\right)$ are the mean values during 10 experimental days under dry weather conditions.

\begin{tabular}{lllll}
\hline $\begin{array}{l}\text { Time } \\
(\mathrm{h})\end{array}$ & $\begin{array}{l}\mathrm{T}_{2,51} \\
\left({ }^{\circ} \mathrm{C}\right)\end{array}$ & $\begin{array}{l}\mathrm{T}_{\mathrm{s}} \\
\left({ }^{\mathrm{C}} \mathrm{C}\right)\end{array}$ & $\begin{array}{l}\mathrm{R}_{\mathrm{g}} \\
\left(\mathrm{Jcm}^{-2} \mathrm{~h}^{-1}\right)\end{array}$ & $\begin{array}{l}\Delta \\
(\%)\end{array}$ \\
8 & 17.0 & 20.3 & & \\
9 & 18.4 & 22.9 & 48 & 0.11 \\
10 & 19.9 & 25.7 & 99 & 0.16 \\
11 & 21.2 & 27.3 & 156 & 0.29 \\
12 & 21.5 & 27.8 & 187 & 0.39 \\
13 & 22.2 & 28.1 & 219 & 0.42 \\
14 & 22.6 & 29.3 & 269 & 0.45 \\
15 & 22.9 & 30.0 & 267 & 0.51 \\
16 & 23.1 & 28.8 & 248 & 0.54 \\
17 & 23.0 & 27.8 & 241 & 0.40 \\
18 & 23.1 & 27.1 & 197 & 0.29 \\
19 & 22.8 & 25.7 & 152 & 0.24 \\
20 & 21.9 & 24.1 & 117 & 0.15 \\
21 & 20.4 & 21.5 & 70 & 0.09 \\
\hline
\end{tabular}

$\left(14^{\circ} \mathrm{C}\right)$, an air temperature of $26^{\circ} \mathrm{C}$ sets the equilibrium moisture content of wheat at $11.8 \%$ and an air temperature of $23^{\circ} \mathrm{C}$ sets the equilibrium moisture content of barley at $12.4 \%$. Since most of the time the air temperature is lower than given abo$\mathrm{ve}$, the moisture contents of wheat and barley have higher values.

In Fig. 4 the equilibrium moisture content of wheat is equal to that of barley if the air temperature and dew point temperature is $17^{\circ} \mathrm{C}$ and $14^{\circ} \mathrm{C}$, respectively. If the air 


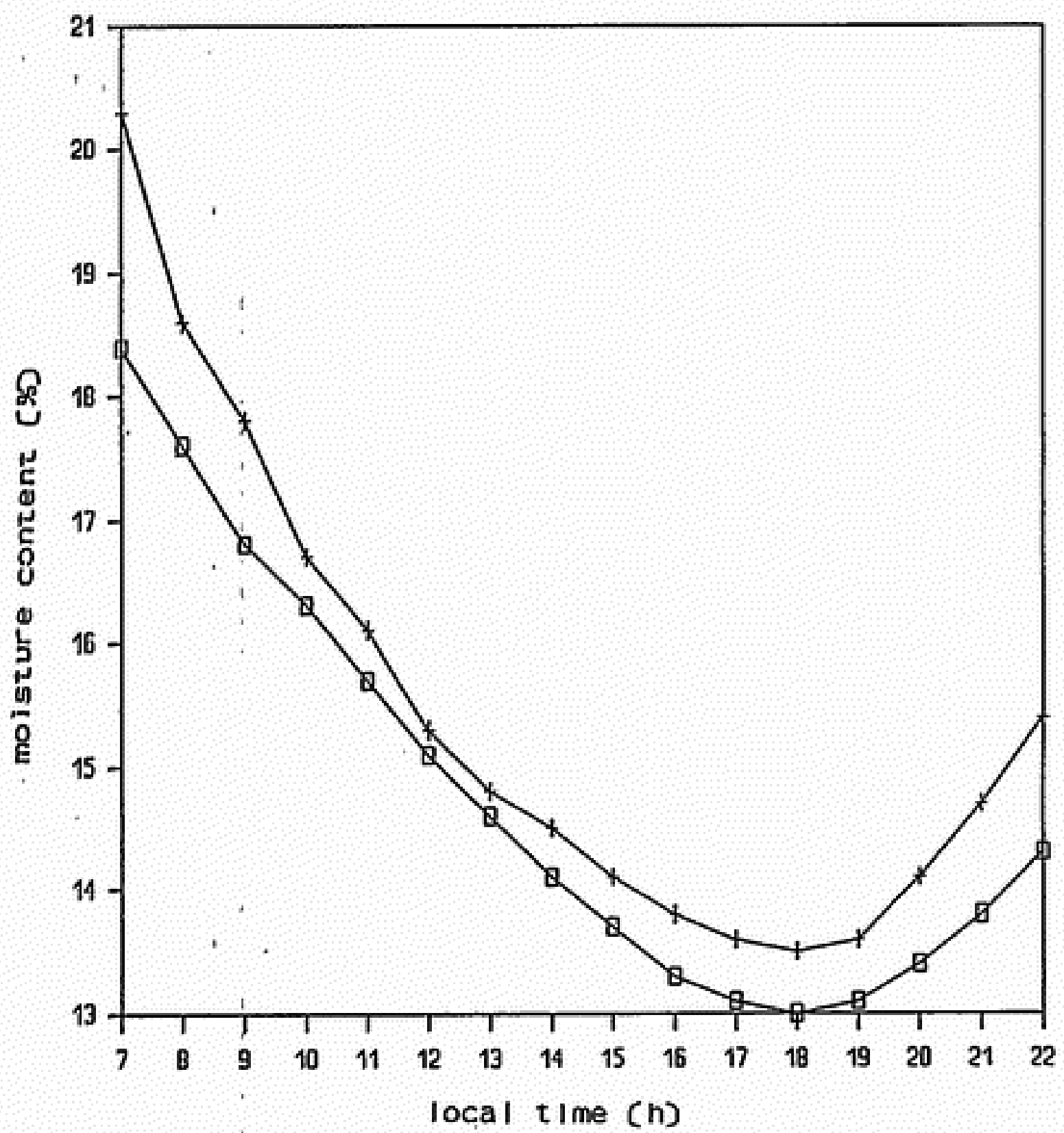

Fig. 3. Course of the average moisture content during the day. $\square$ wheat; + barley.

temperature decreases (and the dew point temperature remains $14^{\circ} \mathrm{C}$ ) the equilibrium moisture content of barley is higher than that of wheat. Usually in the night, when the relative humidity is high, the moisture content of barley is higher than that of wheat under the same weather conditions. The line marked with * in Fig. 5, calculated with equation 3 , represents an equal equilibrium moisture content of wheat and barley. The mark * represents the example of Fig. 4 . In low temperatures with a high humidity the equilibrium moisture content of barley is higher than that of wheat. In a high temperature or a low humidity the equilibrium moisture content of barley is lower than that of wheat.

At combining the grains come into close contact with the straw. In many cases moisture is transferred from straw to grains. If the moisture content (m.c.) of wheat is less than $17.2 \%$, the straw is ripe and no green weeds are present, the differences between the moisture content before and after threshing is small (Van Kampen, 


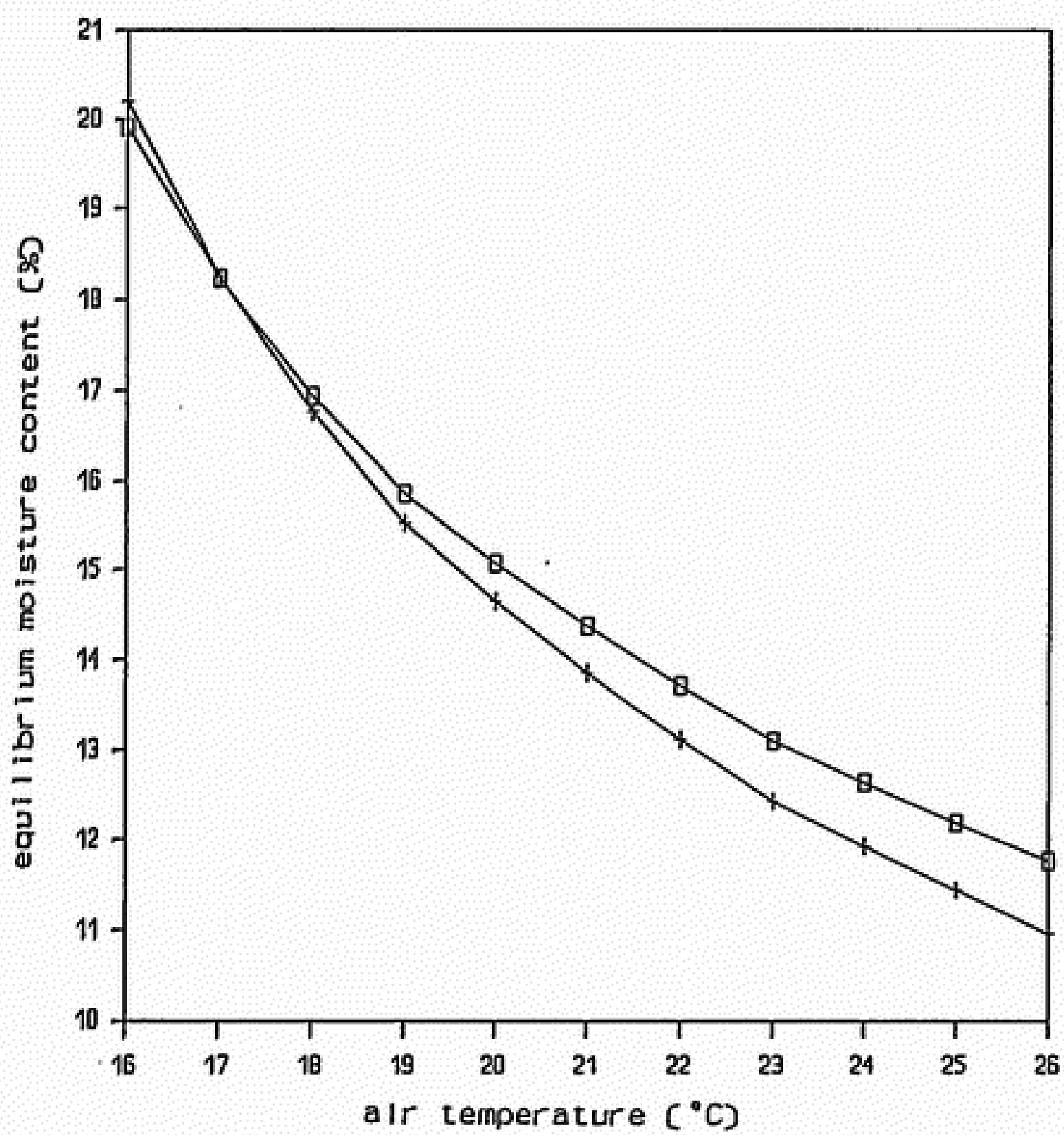

Fig. 4. Equilibrium moisture content versus the air temperature. Dew point temperature is $14^{\circ} \mathrm{C}$. $\square$ wheat; + barlcy.

1969). In our measurements in wheat the mean moisture content before and after threshing was $15.0 \%$ and $15.2 \%$, respectively $(n=21 ;$ m.c. $<17.2 ; 8$ different days).

Quite different were the results of our measurements in barley. The mean moisture content of barley before and after threshing was $13.1 \%$ and $14.7 \%$, respectively (n $=11 ; 4$ different days). Despite a low moisture content the rise in moisture content is $1.6 \%$. The outside of the straw of barley is more smooth than that of wheat.

\section{Conclusions}

Both in wheat and in barley no significant difference is present in the dew point temperature ( $1.5 \mathrm{~m}$ height) between the experimental plot and the nearest weather sta- 


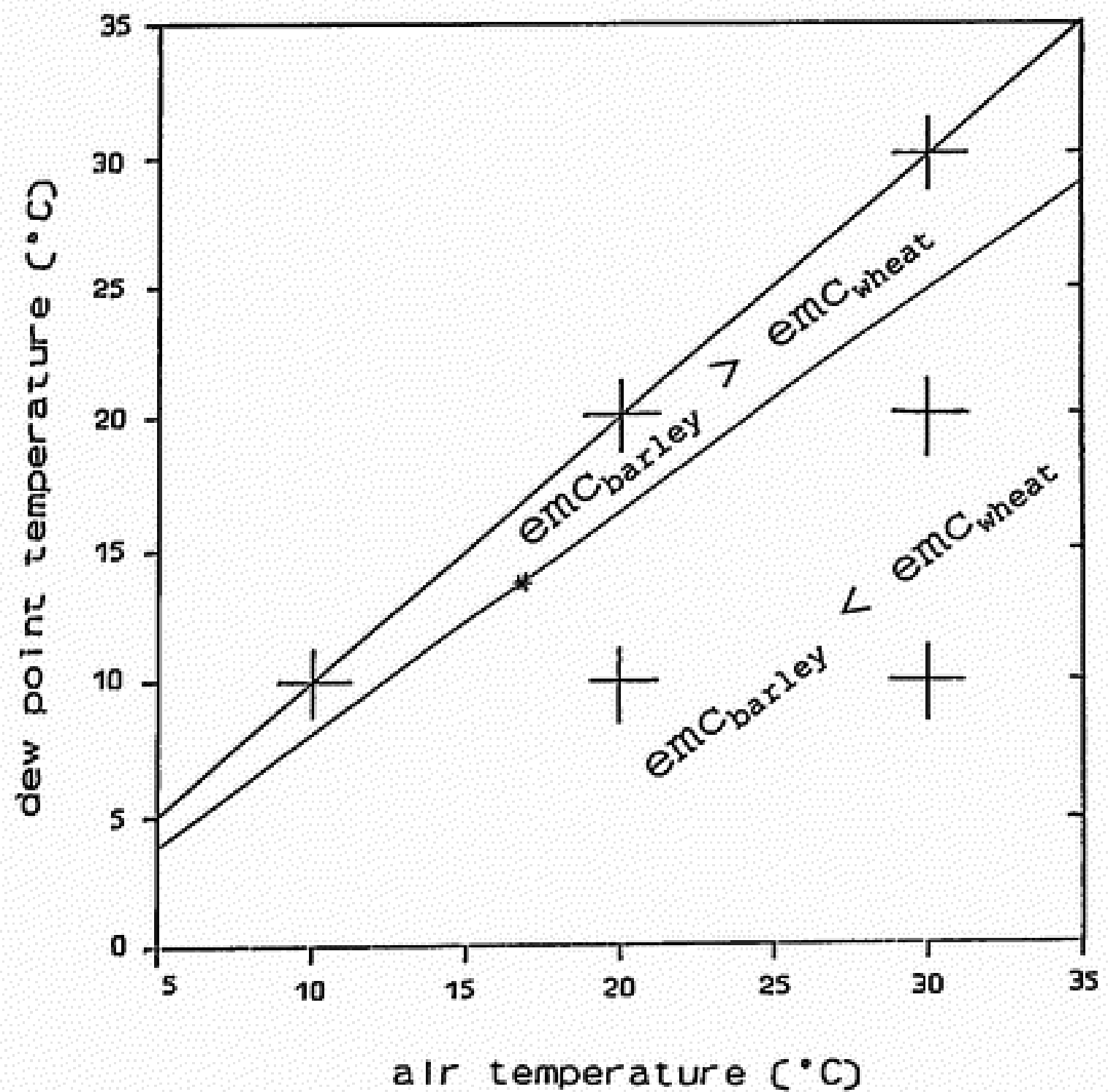

Fig. 5. Equilibrium moisture content (emc) of wheat and barley in relation to dew point temperature and air temperature. The grid $(+)$ is also given.

tion. However the air temperature above wheat and barley is higher than that in the screen. Both for wheat and barley, in daytime the maximum difference between the calculated moisture content is $0.5 \%$, using the air temperature at $1.5 \mathrm{~m}$ height from the nearest standard weather station and the surface temperature of the ears. Because under the same weather conditions, barley absorbs more heat than wheat, the difference in moisture content of barley appears early on the day. Barley has a greater daily cycle in the moisture content of the grains than wheat. In low temperatures with a high humidity the equilibrium moisture content of barley is higher than that of wheat. In a high temperature or in a low humidity the equilibrium moisture content of barley is lower than that of wheat. In wheat the differences between the moisture content before and after threshing is small if the moisture content of wheat is low, the straw is ripe and no green weeds are present. 


\section{Acknowledgements}

Thanks are due to M.P.C. Zeelen and C.A. Hoek for the execution of the field experiments at Kessel and Haamstede, respectively. Credit is also to C. Zeelen, A. Hoek and L.D. Atzema, who made available the facilities for the field experiments at Kessel, Haamstede and Weiwerd, respectively. I express my gratitude to my colleagues J. Birnie and A.D. Welgraven, who supplied the instruments for the field experiments.

\section{References}

Anonymous, 1982. Moisture relationships of grains. Agricultural Engineers Yearbook, ASAE D245.4: 314-318,

Atzema, A.J., 1993. A model for the prediction of the moisture content of cereals at harvesting time with Realtime Weather Data. Journal of Agricultural Engineering Research 54: 245-256.

Beinhauer, R., 1975. The dependence and estimation of differences of temperature of a wheat stand from screen values). (In German). Agricultural Meteorology 15: 87-95.

Henderson, S.M., 1952. A basic concept of equilibrium moisture. Agricultural Engineering 33: 29-32.

Holtslag, A.A.M. \& A.P. van Ulden, 1983. A simple scheme for daytime estimates of the surface fluxes from routine weather data. Journal of Climate and Applied Meteorology 22: 517-529.

Monteith, J,L., 1965. Evaporation and environment. Proceedings, Symposium of the Society for Experimental Biology 19: 205-234.

Monteith, J.L., 1969. Light interception and radiative exchange in crop stands. In: J.D. Eastin, F.A. Haskins, C,Y. Sullivan \& C.H.M. van Bavel (Eds), Physiological aspects of crop yield, p. 89-115. American Socicty of Agronomy and Crop Science Society of America Madison, Wisconsin.

Monteith, J,L. \& M.H. Unsworth, 1990. Principles of environmental physics. Edward Arnold, London, $291 \mathrm{pp}$.

Ross, J., 1975, Radiative transfer in plant communities. In: J.L. Monteith (Ed.), Vegetation and the atmosphere. Vol.1: Principles, p. 13-55. Academic Press, London.

Yan Eimern, J, 1964. Investigations on the climate of agricultural plant covers. (In German). Berichte des Deutschen Wetterdienstes 96: 103 pp.

Van Kampen, J,H., 1969. Optimizing harvesting operations on a large scale grain farm. $\mathrm{PhD}$ Thesis, Wageningen Agricultural University, 176 pp.

\section{Notation}

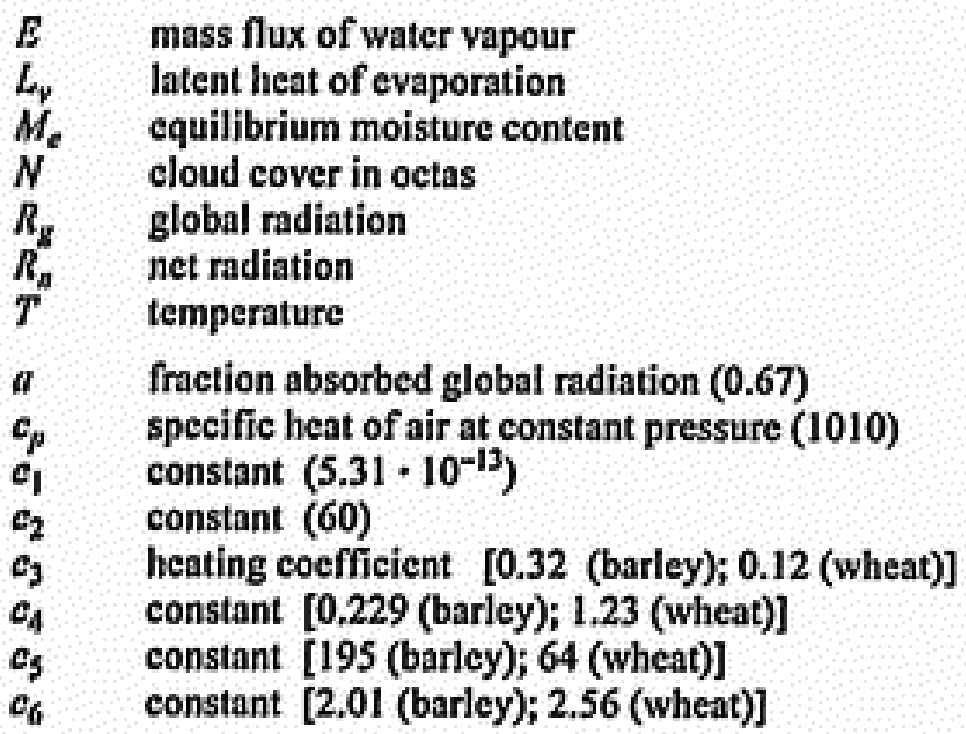

$$
\begin{aligned}
& \mathrm{kg} \mathrm{m}^{-2} \mathrm{~s}^{-1} \\
& \mathrm{~J} \mathrm{~kg}^{-1} \\
& \% \text { wb } \\
& \mathrm{W} \mathrm{\textrm {m } ^ { - 2 }} \\
& \mathrm{W} \mathrm{\textrm {m } ^ { - 2 }} \\
& \mathrm{K} \\
& \\
& \mathrm{J} \mathrm{kg}^{-1} \mathrm{~K}^{-1} \\
& \mathrm{~W} \mathrm{~m}^{-2} \mathrm{~K}^{-6} \\
& \mathrm{~W} \mathrm{~m}^{-2}
\end{aligned}
$$




\section{A.J. ATZEMA}

$e_{a} \quad$ actual vapour pressure

$\mathrm{Pa}$

$c_{s} \quad$ saturated vapour pressure

$r_{a} \quad$ acrodynamic resistance of air

$r_{c} \quad$ crop resistance

$s \quad$ slope of saturation humidity vs temperature curve

$\mathrm{Pa}$

$s \mathrm{~m}^{-1}$

$\mathrm{s} \mathrm{m}^{-1}$

$\gamma \quad$ psychrometric constant

$\mathrm{Pa} \mathrm{K}^{-1}$

$\mathrm{Pa}$ density of air

o Stefan-Boltzmann constant $\left(5.67 \cdot 10^{-8}\right)$

$\mathrm{Pa} \mathrm{K}{ }^{-1}$

$\mathrm{kg} \mathrm{m}^{-3}$

$\mathrm{W} \mathrm{m}^{-4} \mathrm{~K}^{-4}$ 